\title{
REVIEW
}

\section{Procedural Sedation and Analgesia in Adults - new trends in patients safety}

\author{
Mădălina Duţu ${ }^{1,2, *, \dagger}$, Robert Ivascu ${ }^{1,2}$, Darius Morlova ${ }^{1,2}$, Alina Stanca ${ }^{1,2}$, \\ Dan Corneci ${ }^{1,2}$, Silvius Negoita ${ }^{1,2}$ \\ ${ }^{1}$ Anesthesiology and Critical Care Department, Elias Clinical Emergency Hospital, Bucharest, Romania; \\ ${ }^{2}$ Faculty of Medicine, Carol Davila University of Medicine and Pharmacy, Bucharest, Romania
}

\section{Correspondence to:}

Mădălina Duţu, Anesthesiology and Critical Care Department, Elias Clinical Emergency Hospital, Bucharest, Romania, 17 Marasti Bd, Bucharest, Romania

E-mail: madalinadutu236@yahoo.com

\section{Conflicts of interests}

Nothing to declare

\section{Acknowledgements}

None

Funding: This research did not receive any specific grant from funding agencies in the public, commercial or not-for profit sectors.

Keywords: procedural sedation and analgesia; monitored anesthesia care; level of sedation; respiratory complication and discharge criteria.

These authors take responsibility for all aspects of the reliability and freedom from bias of the data presented and their discussed interpretation.

Central Eur J Clin Res 2019;2(1):11-22

Received: 10.09.2018, Accepted: 02.01.2019, Published: 1.02.2019

Copyright () 2019 Central European Journal of Clinical Research. This is an open-access article distributed under the Creative Commons Attribution License, which permits unrestricted use, distribution, and reproduction in any medium, provided the original work is properly cited.

\section{Abstract}

Sedation and analgesia may be needed for many interventional or diagnostic procedures, whose number has grown exponentially lately. The American Society of Anesthesiologists introduced the term "procedural sedation and analgesia" (PSA) and clarified the terminology, moderate sedation and Monitored Anesthesia Care. This review tries to present a nondissociative sedation classification, follow- ing ASA guidelines as well as pre-procedural assessment and preparation, in order to choose the appropriate type and level of sedation, patient monitoring and agents, which are most commonly used for sedation and/or analgesia, along with their possible side effects. The paper also lists the possible complications associated with PSA and a few specific particularities of procedural sedation.

\section{Definition}

Modern medicine often requires proce- 
dures that can cause pain and anxiety. Procedural sedation and analgesia imply the administration of sedative medication, with or without analgesics, in order to improve patient comfort and facilitate a procedure's performance in elective or emergency acute care medicine, for both in and out-patients, inside or outside the operating room [1].

The American Society of Anesthesiologists (ASA, Schaumburg, IL, USA), published in 2002, "Practice Guidelines for Sedation and Analgesia by Non-Anesthesiologists," where the oxymoronic expression "conscious sedation" has been replaced by "procedural sedation and analgesia" (PSA), because sedation is seen as a continuous state whose staging needs more than a responsiveness criterion [2,3]. Procedural sedation is called "appropriate" when airway control and spontaneous respiration are maintained, despite depressed levels of consciousness [1].

Changing terminology, between PSA and Monitored Anesthesia Care (MAC), created confusion. To clarify the definitions, the European Society of Anesthesiology (ESA, Brussels, Belgium) guidelines 2017 state that Monitored Anesthesia Care (MAC) is mainly PSA, when provided by an anesthesiologist.

The ASA's statement, Distinguishing Monitored Anesthesia Care ("MAC") from Moderate Sedation/Analgesia (Conscious Sedation), issued in August 2018, clarifies that MAC is "clearly distinct from Moderate Sedation due to the expectations and qualifications of the provider, who must be able to utilize all anesthesia resources to support life and to provide patient comfort and safety during a diagnostic or therapeutic procedure" [4].
In conclusion, MAC services are rendered by anesthesia providers, who are not involved in the diagnostic or procedural service and include the same care as any other anesthesia service: a pre-anesthesia assessment, vital signs monitoring during the procedure, and post anesthesia patient care [5].

The demand for sedation and analgesia has increased due to the use of invasive endoscopy and radiology, as a first line treatment for many life-threatening conditions, screening campaigns over the past decades, as well as patients' rising expectations and the need to improve their compliance [6].

\section{Classification}

The 2002 ASA guidelines classify the level of non-dissociative sedation into 4 categories, taking into account the criteria of responsiveness, airway patency, and ability to maintain spontaneous ventilation and cardiovascular depression. The guidelines emphasize that sedation is a gradual, continuous state of central nervous system depression, from mere anxiolysis to general anesthesia [7].

The classification does not apply to the dissociative state specific to ketamine, characterized by analgesia, amnesia and sedation, with the preservation of protective airway reflexes and spontaneous respiration. In ketamine sedation, once the dissociative effect is reached, the patient remains unresponsive to any stimulus, and the cardio-respiratory function is preserved, regardless of supplementary doses [8].

Table 1. ASA classification of sedation levels [7].

\begin{tabular}{|c|c|c|c|c|}
\hline & $\begin{array}{l}\text { Minimal } \\
\text { Sedation } \\
\text { (Anxiolysis) }\end{array}$ & $\begin{array}{l}\text { Moderate } \\
\text { Sedation/ } \\
\text { Analgesia }\end{array}$ & $\begin{array}{l}\text { Deep Sedation/ } \\
\text { Analgesia }\end{array}$ & $\begin{array}{c}\text { General } \\
\text { Anesthesia }\end{array}$ \\
\hline Responsiveness & $\begin{array}{l}\text { Normal } \\
\text { response } \\
\text { to verbal } \\
\text { stimulation }\end{array}$ & $\begin{array}{l}\text { Purposeful } \\
\text { response to } \\
\text { verbal or tactile } \\
\text { stimulation }\end{array}$ & $\begin{array}{l}\text { Purposeful } \\
\text { response after } \\
\text { repeated or painful } \\
\text { stimulation }\end{array}$ & $\begin{array}{c}\text { Unresponsive, } \\
\text { even with } \\
\text { painful stimuli }\end{array}$ \\
\hline Airway patency & Unaffected & $\begin{array}{l}\text { No intervention } \\
\text { needed }\end{array}$ & $\begin{array}{l}\text { May require } \\
\text { intervention }\end{array}$ & $\begin{array}{l}\text { Intervention } \\
\text { often required }\end{array}$ \\
\hline $\begin{array}{l}\text { Spontaneous } \\
\text { breathing }\end{array}$ & Unaffected & Adequate & May be inadequate & $\begin{array}{l}\text { Frequently } \\
\text { inadequate }\end{array}$ \\
\hline $\begin{array}{l}\text { Cardiovascular } \\
\text { function }\end{array}$ & Unaffected & $\begin{array}{l}\text { Usually } \\
\text { maintained }\end{array}$ & Usually maintained & $\begin{array}{l}\text { May be } \\
\text { impaired }\end{array}$ \\
\hline
\end{tabular}

* Reflex withdrawal from a painful stimulus does not represent a purposeful response. 


\section{When is Patient Sedation and Analgesia Indicated}

Procedural sedation can be employed for any prolonged or unpleasant procedure in order to alleviate the patient's discomfort, pain or anxiety and perform under better conditions.

Patient-related factors: increased anxiety, unwillingness to cooperate and disabilities in understanding.

Procedure-related factors: painful maneuvers, interventions requiring a deep level of relaxation or a minimal amount of patient movement [9].

\section{Pre-Procedural Patient Assessment}

Each patient should be assessed thoroughly and prepared as if undergoing general anesthesia. The assessment choses the adequate level of sedation and evaluates the patient's risk of complications and need for an anesthesiologist [10].

A. Pre-procedural patient evaluation should include a detailed medical history, along with a focused physical examination and laboratory testing. Together with vital signs measurement and baseline consciousness level assessment, airway anatomy evaluation, focusing on predictors for difficult bag-mask ventilation and laryngoscopy, must always be performed rigorously [11]. The best risk stratification tool is the ASA physical status classification. In gastrointestinal endoscopy, for example, patients with a higher ASA status class have a higher risk of unplanned cardiorespiratory complications during the procedure [12].

B. Pre-procedural patient preparation

According to the 2017 ESA guidelines, patients should be referred to an anesthesiologist for evaluation and intra-procedural management in case of severe cardiovascular disease, documented risk of obstructive sleep apnea, morbid obesity (BMI > $40 \mathrm{~kg} / \mathrm{m} 2$ ), chronic liver failure (MELD score $\geq 10$ ), chronic renal failure (glomerular filtration rate $<60 \mathrm{~mL} / \mathrm{min} / 1,73 \mathrm{~m} 2$ for more than 3 months or stage $3 A$ ), elderly patients ( $>70$ years) and ASA status class $\geq \mathrm{III}$ [1]. Increased risk of pulmonary aspiration and airway difficulties should also require the presence of an anesthesiologist $[4,10]$.

Pre-procedural fasting. ASA guidelines recommend a fasting period of $2 \mathrm{~h}$ for clear liquids, $6 \mathrm{~h}$ for light solid meals and $8 \mathrm{~h}$ for fried/ fatty foods or meat in adults undergoing procedural sedation to avoid gastric content aspiration [13]. However, current literature does not provide enough evidence that any specific period of fasting positively influences gastric volumes and $\mathrm{pH}$ [10]. In addition, studies from the literature revealed that the aspiration risk during emergent procedural sedation on non-fasted patients is very low, and pre-procedural fasting for any duration does not decrease the risk of emesis or aspiration [14-16]. A more liberalized pre-sedation fasting policy might be more suitable, observing the current ASA guidelines for patients with a higher risk of aspiration [15].

\section{Limits and Precautions}

There are no absolute contraindications to procedural sedation. However, precautions exist, and they require case management by an anesthesiologist:

status $\geq$ III) significant comorbidities (ASA class

- older age (>70-75 years)

- airway difficulties

- high risk of aspiration.

Recent food intake is not an absolute contraindication, and sedation should not be delayed in emergencies based only on fasting time, although the last food intake should be considered when choosing the timing and degree of sedation $[13,16]$. Conditions predisposing to pulmonary aspiration are: gastroesophageal reflux (hiatus hernia, bowel obstruction, pregnancy), ASA class status $\geq 11$, older age (>70 years), airway difficulties, and depressed mental state [15].

\section{Monitoring}

Patient standard mandatory monitoring during procedural sedation outside the operation room is maintained for non-invasive arterial blood pressure, ECG monitoring, oxygen saturation and end-tidal carbon dioxide (EtCO2) $[1,7]$.

For consciousness assessment, the "gold standard" remains the communication between the anesthetist and the patient. If this is impossible (e.g., upper endoscopy), a way to check the state of consciousness must be established before the beginning of the procedure (e.g., shake hand or lift one finger when asked). Cerebral monitoring has been proven to have a limited utility in procedural sedations. The bispectral index (BIS) technology has been proven to be efficacious in reducing hypnotic doses and procedure duration, without influencing cardiopulmonary complications [17,18]. Gill et al. also demonstrated this device's limitations in differentiating sedation levels [19]. There are 
also other devices, such as Spectral Entropy and Narcotrend, that have recently begun to be evaluated in relation to procedural sedation.

Hemodynamic monitoring involves the non-invasive blood pressure and heart rate at regular intervals. While ASA guidelines 2018 indicate that continued ECG monitoring is mandatory only in cases of moderate sedation of patients with cardiovascular disease or when arrhythmias are anticipated, ESA guidelines 2017 recommend ECG monitoring for all procedural sedations $[1,7]$.

The use of hypnotic drugs and opioids can be accompanied by respiratory depression. Pulse oximetry is mandatory, but this is a late indicator of respiratory depression, especially when supplemental oxygen is added. Oxygen supplementation to prevent hypoxemia is recommended, although this proves beneficial only when using a high flow (15 L/min) [20].

Campbell's study demonstrated that using capnometry did not induce significant changes in clinical outcomes, although a meta-analysis published in 2017 by Sanders et al. concluded that including capnography in standard monitoring was associated with a decrease in moderate and severe desaturations $[21,22]$. However, end-tidal CO2 does not accurately reflect $\mathrm{PaCO} 2$ in non-intubated patients with various preexisting lung disorders [23].

As each current device used for monitoring ventilation is flawed, the research for an

Table 2. The most commonly used drugs for procedural sedation $[26,27]$ ( $N R=$ not reported).

\begin{tabular}{|c|c|c|c|c|c|c|}
\hline Medication & Dose & $\begin{array}{c}\text { Onset } \\
\text { (minutes) }\end{array}$ & $\begin{array}{l}\text { Duration } \\
\text { (minutes) }\end{array}$ & Effects & $\begin{array}{c}\text { Important Side } \\
\text { Effects }\end{array}$ & Comments \\
\hline Propofol & $\begin{array}{l}0.5-1 \\
\mathrm{mg} / \mathrm{kg}\end{array}$ & 0.5 & $4-10$ & $\begin{array}{l}\text { Amnestic } \\
\text { Sedative }\end{array}$ & $\begin{array}{l}\text { Injection site pain } \\
\text { Hypotension } \\
\text { Respiratory de- } \\
\text { pression }\end{array}$ & $\begin{array}{l}\text { The most com- } \\
\text { mon hypnotic } \\
\text { agent used } \\
\text { for procedural } \\
\text { sedation }\end{array}$ \\
\hline Midazolam & $\begin{array}{c}0.03 \\
\mathrm{mg} / \mathrm{kg}\end{array}$ & $1-3$ & 10-20 & $\begin{array}{l}\text { Anxiolytic } \\
\text { Sedative }\end{array}$ & $\begin{array}{l}\text { Respiratory de- } \\
\text { pression }\end{array}$ & $\begin{array}{c}\text { Decreased } \\
\text { clearance in } \\
\text { elderly, critically } \\
\text { ill, hepatic dys- } \\
\text { function }\end{array}$ \\
\hline $\begin{array}{l}\text { Dexmedeto } \\
\text { midine }\end{array}$ & $\begin{array}{c}1 \mathrm{mcg} / \\
\mathrm{kg}\end{array}$ & $<5$ & $30-45$ & $\begin{array}{l}\text { Sedative } \\
\text { Anxiolytic } \\
\text { Amnestic }\end{array}$ & $\begin{array}{c}\text { Hypo-/hyperten- } \\
\text { sion } \\
\text { Nausea } \\
\text { Bradycardia }\end{array}$ & $\begin{array}{c}\text { High cost } \\
\text { Infusing the } \\
\text { loading dose in } \\
10 \text { min }\end{array}$ \\
\hline Ketamine & $\begin{array}{l}0.25-1 \\
\mathrm{mg} / \mathrm{kg}\end{array}$ & $0-5$ & $5-10$ & $\begin{array}{c}\text { Analgesic } \\
\text { Amnestic } \\
\text { Dissociative } \\
\text { sedative }\end{array}$ & $\begin{array}{c}\text { Delirium } \\
\text { Hallucinations } \\
\text { Prolonged recov- } \\
\text { ery }\end{array}$ & $\begin{array}{l}\text { Minimal respira- } \\
\text { tory depression } \\
\text { Airway reflexes } \\
\text { preservation }\end{array}$ \\
\hline
\end{tabular}

ideal one is ongoing. A new non-invasive respiratory monitoring device (impedance-based respiratory volume monitor-RVM), continuously recording a minute expiratory volume, tidal volume and respiratory rate, may prove valuable. RVM use has been shown to decrease the number of apnea and hypoventilation episodes [24]. A pilot study published in 2018 suggests monitoring ventilation using diaphragm ultrasonography [25].

For the time being, according to both ASA and ESA guidelines, the continual monitoring of ventilatory function with capnography, to supplement standard monitoring by observation and pulse oximetry, is mandatory $[1,7]$.

\section{Medication}

At present, there are different ways to obtain the desired level of sedation and analgesia, although the most useful and efficient one remains the intravenous administration of a hypnotic drug, with the addition of an analgesic (usually opioid) in painful procedures. The "ideal" substance should have a rapid onset, a rapid recovery time, a known pharmacodynamic and pharmacokinetic profile and should not produce respiratory or hemodynamic depression [26]. The most commonly used substances are described in the table below (Table 2). 
Procedural Sedation and Analgesia in Adults

\begin{tabular}{|c|c|c|c|c|c|c|}
\hline Fentanyl & $\begin{array}{c}0.5-1 \\
\mathrm{mcg} / \mathrm{kg}\end{array}$ & $2-3$ & $30-60$ & Analgesic & $\begin{array}{c}\text { Respiratory de- } \\
\text { pression } \\
\text { Muscle rigidity }\end{array}$ & $\begin{array}{c}\text { Minimal hypo- } \\
\text { tension }\end{array}$ \\
\hline Remifentanil & $\begin{array}{c}1 \mathrm{mcg} / \\
\mathrm{kg}\end{array}$ & $1-1.5$ & $5-10$ & Analgesic & $\begin{array}{c}\text { Respiratory de- } \\
\text { pression } \\
\text { Muscle rigidity }\end{array}$ & $\begin{array}{c}\text { Minimal central } \\
\text { nervous system } \\
\text { depression } \\
\text { Usually used } \\
\text { in combination } \\
\text { with hypnotics }\end{array}$ \\
\hline Remimazolam & $\begin{array}{c}0.1-0.2 \\
\mathrm{mg} / \mathrm{kg}\end{array}$ & $1-3$ & $10-40$ & Sedative & NR * & $\begin{array}{c}\text { Market approval } \\
\text { in procedural } \\
\text { sedation ongo- } \\
\text { ing }\end{array}$ \\
\hline Fospropofol & $\begin{array}{c}5-8 \\
\mathrm{mg} / \mathrm{kg}\end{array}$ & $4-8$ & $5-18$ & $\begin{array}{c}\text { Sedative } \\
\text { Amnestic }\end{array}$ & $\begin{array}{c}\text { Pruritus } \\
\text { Paresthesia } \\
\text { Hypotension } \\
\text { Respiratory de- } \\
\text { pression }\end{array}$ & $\begin{array}{c}\text { Much more } \\
\text { expensive than } \\
\text { propofol }\end{array}$ \\
\hline
\end{tabular}

\section{Complications}

In 2016, Bellolio et al. published two meta-analyses of complications in adults and children relating to procedural sedation in emergency departments. No deaths were recorded. The most frequent major complications in adults were laryngospasm (4.2/1000 cases), followed by the need to intubate $(1.6 / 1000$ cases), and pulmonary aspiration (1.2/1000 cases), while the most common minor complications were transient hypoxia (40/1000 cases), vomiting, arterial hypotension and transient apnea $[28,29]$ (Table 3).

Table 3. Most important complications of procedural sedation and analgesia.

\begin{tabular}{|c|c|c|}
\hline Complication & Cause and Risk Factors & Description \\
\hline \multicolumn{3}{|l|}{$\begin{array}{l}\text { Respiratory } \\
\text { Complications }\end{array}$} \\
\hline $\begin{array}{c}\text { Respiratory depression } \\
\text { (hypoventilation/apnea) } \\
{[30,31]}\end{array}$ & $\begin{array}{l}\text { Use of sedative (especially } \\
\text { propofol, benzodiazepines } \\
\text { and etomidate) and opioid } \\
\text { medication }\end{array}$ & $\begin{array}{l}\text { Dose-dependent decrease of central } \\
\text { and peripheral chemoreceptors } \\
\text { sensitivity and direct respiratory } \\
\text { centers depression. }\end{array}$ \\
\hline \multicolumn{3}{|l|}{ Airways Obstruction: } \\
\hline Airway collapse $[32,33]$ & $\begin{array}{c}\text { Obesity } \\
\text { Sleep apnea syndrome }\end{array}$ & $\begin{array}{l}\text { Posterior collapse of the pharyngeal } \\
\text { structures and epiglottis }\end{array}$ \\
\hline Laryngospasm $[30,32,34]$ & $\begin{array}{c}\text { Children } \\
\text { Smokers } \\
\text { ENT and dental procedures }\end{array}$ & $\begin{array}{l}\text { Irritation produced by secretions or } \\
\text { blood, followed by reflex closure of the } \\
\text { striate muscles of the glottis. }\end{array}$ \\
\hline Glottis edema [30] & History of allergic episodes & $\begin{array}{l}\text { Anaphylactic reaction, leading to } \\
\text { swelling of the glottis mucosa }\end{array}$ \\
\hline Bronchospasm $[30,32]$ & $\begin{array}{c}\text { History of allergic episodes } \\
\text { Bronchial hyper reactivity } \\
\text { (including asthma) } \\
\text { Aspiration of gastric content or } \\
\text { secretions } \\
\text { Smoking } \\
\text { Use of histamine-triggering } \\
\text { medication }\end{array}$ & $\begin{array}{l}\text { Bronchial smooth muscle contraction, } \\
\text { as a response to direct irritation or } \\
\text { triggered by an anaphylactic reaction }\end{array}$ \\
\hline
\end{tabular}




\begin{tabular}{|c|c|c|}
\hline $\begin{array}{l}\text { Pulmonary aspiration } \\
\qquad[30,35]\end{array}$ & $\begin{array}{c}\text { Obesity } \\
\text { Hiatal hernia } \\
\text { Pregnancy } \\
\text { Sedation for endoscopy } \\
\text { Full stomach }{ }^{* *} \text { ) }\end{array}$ & $\begin{array}{l}\text { Loss of protective reflexes can lead } \\
\text { to aspiration of gastric content, blood, } \\
\text { secretions, and teeth. This can lead to } \\
\text { airway obstruction and/or pneumonia, } \\
\text { with pulmonary abscesses or acute } \\
\text { respiratory distress syndrome. }\end{array}$ \\
\hline \multicolumn{3}{|l|}{$\begin{array}{l}\text { Cardiovascular } \\
\text { Complications }\end{array}$} \\
\hline Arterial hypotension [30] & $\begin{array}{l}\text { Hypovolemia } \\
\text { Shock states }\end{array}$ & $\begin{array}{c}\text { Some sedatives (propofol, } \\
\text { benzodiazepines) reduce cardiac } \\
\text { frequency, stroke volume and vascular } \\
\text { resistance. }\end{array}$ \\
\hline Bradycardia [32] & $\begin{array}{l}\text { Beta-blocker treatment } \\
\text { Previous cardiac blocks }\end{array}$ & $\begin{array}{c}\text { Can be induced by cardiac depressant } \\
\text { effect of sedative medication and/or by } \\
\text { vasovagal reflexes. }\end{array}$ \\
\hline Anaphylactic shock [36] & $\begin{array}{c}\text { Atopy with or without history of } \\
\text { allergic episodes }\end{array}$ & $\begin{array}{l}\text { Massive histamine and other } \\
\text { mediators release with vasodilation } \\
\text { and increased vascular permeability, } \\
\text { with loss of intravascular volume } \\
\text { leading to distributive shock. }\end{array}$ \\
\hline $\begin{array}{c}\text { Hypertension and } \\
\text { tachycardia/Onset of new } \\
\text { tachyarrythmia }\end{array}$ & $\begin{array}{c}\text { Pain } \\
\text { Use of ketamine }\end{array}$ & $\begin{array}{l}\text { Related to the increased tone of the } \\
\text { sympathetic nervous system. }\end{array}$ \\
\hline $\begin{array}{l}\text { Acute coronary } \\
\text { syndrome }\end{array}$ & $\begin{array}{l}\text { Previous history of myocardial } \\
\text { ischemia/infarction } \\
\text { Pain } \\
\text { Prolonged hypotension/hypoxia }\end{array}$ & $\begin{array}{c}\text { Imbalance between myocardial } \\
\text { oxygen consumption (tachycardia) } \\
\text { and oxygen delivery (existing coronary } \\
\text { lesions, hypotension, hypoxia). }\end{array}$ \\
\hline Cardiac arrest [37] & $\begin{array}{l}\text { Prolonged hypoxia } \\
\text { Preexisting heart disease } \\
\text { Acute coronary syndrome }\end{array}$ & $\begin{array}{c}\text { All complications listed above can lead } \\
\text { to cardiac arrest, if severe enough or } \\
\text { insufficiently treated. }\end{array}$ \\
\hline \multicolumn{3}{|l|}{$\begin{array}{l}\text { Neuro-Psychiatric } \\
\text { Complication }\end{array}$} \\
\hline $\begin{array}{l}\text { Postoperative delirium } \\
\text { [38] }\end{array}$ & $\begin{array}{l}\text { Elderly } \\
\text { Preexistent cognitive impairment } \\
\text { Use of benzodiazepines } \\
\text { Profound sedation }\end{array}$ & $\begin{array}{c}\text { Acute confusional state, with } \\
\text { fluctuating changes in consciousness } \\
\text { and attention. }\end{array}$ \\
\hline $\begin{array}{l}\text { Emergence delirium } \\
\qquad[39,40]\end{array}$ & $\begin{array}{l}\text { Use of ketamine (in adults) or } \\
\text { volatile agents (in children) } \\
\text { Male sex } \\
\text { Postoperative pain }\end{array}$ & $\begin{array}{l}\text { Agitation, confusion, disorientation, } \\
\text { sometimes violent behavior in early } \\
\text { post-sedation recovery. }\end{array}$ \\
\hline Brain injuries [41] & $\begin{array}{c}\text { Stroke } \\
\text { Prolonged hypoxia }\end{array}$ & $\begin{array}{l}\text { Incomplete or no recovery of pre- } \\
\text { procedural neurological status when } \\
\text { sedative medication was antagonized/ } \\
\text { metabolized, after ruling out metabolic } \\
\text { causes (hypoglycemia, hypercapnia). }\end{array}$ \\
\hline \multicolumn{3}{|l|}{$\begin{array}{l}\text { Thermoregulation } \\
\text { disorders }\end{array}$} \\
\hline Hypothermia $[42,43]$ & $\begin{array}{l}\text { Low environmental temperature } \\
\text { Pediatric population } \\
\text { BMl }<25 \mathrm{~kg} / \mathrm{m} 2 \\
\text { Prolonged procedures }\end{array}$ & $\begin{array}{l}\text { Loss of heat because of vasodilation, } \\
\text { induced by sedatives, and/or impaired } \\
\text { thermoregulation, induced by opioids. }\end{array}$ \\
\hline
\end{tabular}


Procedural Sedation and Analgesia in Adults

\begin{tabular}{|c|c|c|}
\hline $\begin{array}{c}\text { Malignant hyperthermia } \\
{[43,44]}\end{array}$ & $\begin{array}{c}\text { Genetic background } \\
\text { Use of volatile agents }\end{array}$ & $\begin{array}{c}\text { Calcium channel genetic disorder, } \\
\text { triggered by some medication, } \\
\text { rhabdomyolysis, hypercapnia, and } \\
\text { increased heat production }\end{array}$ \\
\hline Other complications & Use of volatile agents and/or \\
opioids \\
$\begin{array}{c}\text { Non-smokers } \\
\text { and vomiting } \\
\text { (PONV) } \\
{[45]}\end{array}$ & $\begin{array}{c}\text { Female sex } \\
\text { History of PONV/motion } \\
\text { sickness }\end{array}$ & $\begin{array}{c}\text { Activation of } \mu \text { opioid receptors and } \\
\text {-HT3 receptor (enhanced by volatile } \\
\text { agents leads to stimulation of the } \\
\text { emesis center. }\end{array}$ \\
\hline $\begin{array}{c}\text { Urinary retention } \\
{[46]}\end{array}$ & $\begin{array}{c}\text { Use of opioids } \\
\text { Prostate hypertrophy } \\
\text { Elderly }\end{array}$ & $\begin{array}{c}\text { Opioid related inhibition of } \\
\text { acetylcholine release from the } \\
\text { parasympathetic sacral neurons } \\
\text { results in urinary retention }\end{array}$ \\
\hline
\end{tabular}

Respiratory complications, regardless of the cause, lead to hypoxemia and hypercapnia. If undiag-

nosed or insufficiently treated, they will progress to tissue hypoxemia and mixed acidosis, with serious consequences (myocardial depression or ischemia, brain hypoxic injuries and cardiac arrest). Being an objective parameter evaluated by pulse oximetry, hypoxemia or the duration of desaturation is considered by some studies as a respiratory complication. The need to intubate implies the existence of a severe respiratory complication or the failure of other treatment options, being counted as a complication itself $[30,32]$.

Traditionally, the lack of preoperative fasting is thought to be a risk factor for aspiration, although multiple studies failed to find a correlation. Bach et al. studied 100,000 cases of procedural sedation, with a known fasting status, and did not find any correlation between fasting and the 8 cases of gastric aspiration [47]. A systematic review, published in 2017 by Green et al., trying to catalogue instances of aspiration involving procedural sedation, identified few occurrences, outside of gastrointestinal endoscopy, where a full recovery was typical. The authors' conclusion was that aspiration during procedural sedation appears to be rare, idiosyncratic, and typically benign [48].

\section{Discharge Criteria}

ESA guidelines recommend several criteria for patient discharge:

The risk of post-procedural complications must be low (e.g., hemorrhage).

Mental and biological status should be close to the pre-procedural parameters, with stable vital signs (arterial pressure, cardiac frequency, oxygen saturation).

Symptoms, such as vomiting, pain, and dizziness, should be controlled.

The patient should be accompanied by a reliable person for the following hours [1].
There are scores, developed to assess patients' suitability for discharge, such as Aldrete and Modified PADSS (Post-Anesthetic Discharge Scoring System), both of which are safe to perform $[49,50]$.

A minimum of 30 min of recovery time in a monitored area, in the presence of a trained nurse, with continuous oxygen saturation and intermittent ECG and noninvasive invasive blood pressure, is recommended before discharge $[1,7]$. Studying the incidence and timing of complications, Newman et al. found that, after $25 \mathrm{~min}$ from the last sedative administration, their occurrence was rare, and no side effects related to sedation occurred after 25 min [51].

\section{Specific Procedural Sedation Particularities}

\section{Sedation for Gastroenterological Procedures}

The challenges related to endoscopic procedures, although not highly invasive nor painful, are associated with difficult airway access, higher risk of aspiration due to gastric bleeding or hemodynamic instability, caused either by hypovolemia (following massive bleeding or bowel preparation) or by a vagal response after digestive tract distention [4].

Choosing the sedation target in endoscopy procedures depends on:

Patient-associated factors: older non-anxious males, without a history of abdominal pain, tend to tolerate upper endoscopy or colonoscopy, with minimal or no sedation. Prior difficulties during procedural sedation, benzodiazepine, opioid or alcohol use predict poor procedural tolerance $[9,52]$.

Procedure-associated factors: long duration, high invasiveness, increased level of dis- 
comfort induced and a need to reduce patient movements (ERCP or EUS-FNA) require deeper levels of sedation [52,53].

At present, most endoscopists prefer midazolam, alone or in combination with an opioid, for procedural sedation $[53,54]$. Due to its short induction and recovery times and improved patient and endoscopist satisfaction, propofol is slowly becoming the best sedation agent for endoscopy, especially during prolonged or complex therapeutic procedures (EUS, ERCP, PEG) [54]. However, because of its narrow therapeutic window and lack of specific antidote, procedural sedation with propofol remains tightly regulated, and many experts recommend that it be performed only by clinicians trained in general anesthesia. In some countries, such as the US, Germany and Switzerland, propofol can be administered by registered nurses or gastroenterologists in low-risk patients, targeting a lower level of sedation [55].

In emergency endoscopy for upper intestinal bleeding, the best anesthetic management is still controversial. Besides clear indications for endotracheal intubation, such as altered mental status and hemodynamic instability, the current literature does not provide any evidence that routinely prophylactic intubation results in a better outcome, compared to minimal or moderate sedation. On the contrary, prophylactic intubation might be associated with higher rates of aspiration [56].

\section{Sedation for Gynecological Procedures}

Paracervical block can be an efficient analgesic technique during diagnostic and less painful therapeutic procedures. In more invasive procedures (therapeutic hysteroscopy), conscious sedation can be used in combination with a paracervical block, providing better post-procedural analgesia and a shorter recovery time than general anesthesia. Regional and general anesthesia should be reserved for interventions with extensive intrauterine manipulation [57-59].

Procedural sedation can also be employed for in vitro fertilization maneuvers. Moderate sedation is generally effective during oocyte retrieval, especially when combined with paracervical block or acupuncture [60], but it might need to be deepened during more painful moments (needle penetration of the cul-de-sac and each ovary) to prevent patient movement. Thus, the most satisfactory technique for both the patient and gynecologist remains total intravenous anesthesia with propofol and an opioid
[61]. Transabdominal gamete or embryo transfer procedures are more invasive, requiring local, neuraxial or general anesthesia.

\section{Sedation for Cardiologic Procedures}

Providing sedation for cardiologic procedures is challenging due to the unfamiliar remote location, limited help from fellow anesthesiologists, limited equipment, radiation exposure, limited access to the patient and a higher risk patient population with severe cardiovascular or pulmonary disease $[62,63]$. Regardless of the technique used, it is important to minimize the effects of anesthetic drugs on the cardiovascular system [64]. Short procedures without hemodynamic instability are manageable under minimal or moderate sedation performed by registered nurses or cardiologists. Anesthetic management is mandatory in patients with severe anxiety, an inability to lay down in supine position, morbid obesity, airway difficulties or significant comorbidities, as well as procedures requiring minimal patient movement or endotracheal intubation [63].

During electrophysiological studies, minimal patient movements, preventing catheter dislodgement and minimal cardiac rhythm depression by anesthetic drugs, in order to be able to reproduce arrhythmias, are compulsory. Most cases are performed under moderate or deep sedation induced by a propofol and remifentanil infusion $[63,65]$.

Some cardiac catheterization procedures, such as percutaneous coronary intervention, implantable cardioverter defibrillator or cardiac pacing device implantation, can be performed under local anesthesia and moderate sedation, administered by the interventional cardiologist. Electrical cardioversion requires a short period of deep sedation, usually acquired by small bolus doses of propofol. Transesophageal echocardiography is also usually performed under procedural sedation (induced by propofol or midazolam), along with pharyngeal anesthesia [63].

\section{Conclusions}

In relation to patient- and procedure-related factors, there is a choice between procedural sedation, analgesia and monitored anesthesia care. In order to support life and provide patient comfort and safety during a diagnostic or therapeutic procedure, the procedural sedation provider must be familiar with the pharmacodynamics of the drug and its possible side effects 
and has to know when patients should be referred to an anesthesiologist for evaluation and intra-procedural management.

\section{References}

1. Hinkelbein J, Lamperti M, Akeson J, Santos J, Costa J, De Robertis E et al. European Society of Anaesthesiology and European Board of Anaesthesiology guidelines for procedural sedation and analgesia in adults. European Journal of Anaesthesiology. 2017; 35:6-24.

2. Practice Guidelines for Sedation and Analgesia by Non-Anesthesiologists. An Updated Report by the American Society of Anesthesiologists Task Force on Sedation and Analgesia by Non-Anesthesiologists. Anesthesiology. 2002; 96(4):1004-1017.

3. Sheta S. Procedural sedation analgesia. Saudi Journal of Anaesthesia. 2010;4(1):11.

4. American Society of Anesthesiologists (ASA). Position on monitored anesthesiacare(AmendedOctober16,2013).2013;http://www.asahq.org/ / media/sites/asahq/files/public/resources/ standardsguidelines/position-on-monitored-anesthesia-care.pdf. (Accessed November 12, 2018).

5. American Society of Anesthesiologists (ASA). Distinguishing monitored Anesthesia care ("MAC") from moderate sedation/analgesia (Amended October 21, 2009 and reaffirmed October 2013). 2013; http://www.asahq.org/ /media/sites/asahq/ files/public/resources/standards-guidelines/distinguishingmonitored-anesthesia-care-from-moderate-sedation-analgesia.pdf. Accessed November 12, 2018.

6. Youn A, Ko Y, Kim Y. Anesthesia and sedation outside of the operating room. Korean Journal of Anesthesiology. 2015; 68(4):323

7. Practice Guidelines for Moderate Procedural Sedation and Analgesia 2018. A Report by the American Society of Anesthesiologists Task Force on Moderate Procedural Sedation and Analgesia, the American Association of Oral and Maxillofacial Surgeons, American College of Radiology, American Dental Association, American Society of Dentist Anesthesiologists, and Society of Interventional Radiology. Anesthesiology. 2018; 128(3):437-479.

8. Green S, Roback M, Kennedy R, Krauss B. Clinical Practice Guideline for Emergency Department Ketamine Dissociative Sedation: 2011 Update. Annals of Emergency Medicine. 2011; 57(5):449-61.
9. Early D, Lightdale J, Vargo J, Acosta R, Chandrasekhara V, Chathadi $\mathrm{K}$ et al. Guidelines for sedation and anesthesia in GI endoscopy. Gastrointestinal Endoscopy. 2018; 87(2):327-337.

10. Burbano-Paredes C, Amaya-Guio J, Rubiano-Pinzón A, Hernández-Caicedo Á, Grillo-Ardila C. Clinical practice guideline for the management of sedation outside of operating room in patients over 12 years. Colombian Journal of Anesthesiology. 2017;45(3):224-238.

11. Moran T, Kaye A, Mai A, Bok L. Sedation, Analgesia, and Local Anesthesia: A Review for General and Interventional Radiologists. RadioGraphics. 2013; 33(2):E47-E60.

12. Enestvedt B, Eisen G, Holub J, Lieberman D. Is the American Society of Anesthesiologists classification useful in risk stratification for endoscopic procedures?. Gastrointestinal Endoscopy. 2013; 77(3):464-471.

13. Practice Guidelines for Preoperative Fasting and the Use of Pharmacologic Agents to Reduce the Risk of Pulmonary Aspiration. An Updated Report by the American Society of AnesthesiologistsTask Force on Preoperative Fasting and the Use of PharmacologicAgents to Reduce the Risk of Pulmonary Aspiration. Anesthesiology. 2017; 126(3):376-393.

14. Molina J, Lobo C, Goh H, Seow E, Heng B. Review of studies and guidelines on fasting and procedural sedation at the emergency department. International Journal of Evidence-Based Healthcare. 2010; 8(2):7578.

15. Thorpe R, Benger J. Pre-procedural fasting in emergency sedation. Emergency Medicine Journal. 2010; 27(4):254-261.

16. Godwin SA, Burton JH, Gerardo CJ, Hatten BW, Mace SE, Silvers S et al. Clinical Policy: Procedural Sedation and Analgesia in the Emergency Department. Annals of Emergency Medicine. 2014; 63(2):247258.e18.

17. Bell J, Laasch $H$, Wilbraham L, England R, Morris J, Martin D. Bispectral index monitoring for conscious sedation in intervention: better, safer, faster. Clinical Radiology. 2004; 59(12):1106-1113.

18. Von Delius $S$, Salletmaier $H$, Meining $A$, Wagenpfeil S, Saur D, Bajbouj $M$ et al. Bispectral index monitoring of midazolam and propofol sedation during endoscopic retrograde cholangiopancreatography: a randomized clinical trial (the EndoBIS study). Endoscopy. 2012; 44(03):258-264.

19. Gill M, Green S, Krauss B. A study of the 
bispectral index monitor during procedural sedation and analgesia in the emergency department. Annals of Emergency Medicine. 2003; 41(2):234-241.

20. Deitch K, Chudnofsky C, Dominici P, Latta D, Salamanca Y. The Utility of High-Flow Oxygen During Emergency Department Procedural Sedation and Analgesia With Propofol: A Randomized, Controlled Trial. Annals of Emergency Medicine. 2011; 58(4):360-364.e3.

21. Campbell S. End-tidal capnometry during emergency department procedural sedation and analgesia: a randomized, controlled study. World Journal of Emergency Medicine. 2016; 7(1):13..

22. Saunders R, Struys M, Pollock R, Mestek $M$, Lightdale J. Patient safety during procedural sedation using capnography monitoring: a systematic review and meta-analysis. BMJ Open. 2017; 7(6):e013402.

23. Jabre $P$, Jacob L, Auger H, Jaulin C, Monribot $\mathrm{M}$, Aurore A et al. Capnography monitoring in nonintubated patients with respiratory distress. The American Journal of Emergency Medicine. 2009; 27(9):10561059.

24. Mathews $D$, Oberding $M$, Simmons $E$, O'Donnell S, Abnet K, MacDonald K. Improving patient safety during procedural sedation via respiratory volume monitoring: A randomized controlled trial. Journal of Clinical Anesthesia. 2018; 46:118-123.

25. Kilicaslan A, Gok F, Gunuc H. Continous monitoring of ventilation by diaphragm ultrasonography using a new tool during procedural sedation. Journal of Clinical Anesthesia. 2018; 50:12-13.

26. Gan T. Pharmacokinetic and Pharmacodynamic Characteristics of Medications Used for Moderate Sedation. Clinical Pharmacokinetics. 2006; 45(9):855-869.

27. Mueller S, Moore G, MacLaren R. Fospropofol Disodium for Procedural Sedation: Emerging Evidence of its Value?. Clinical Medicine Insights: Therapeutics. 2010; 2:1179559X1000200.

28. Bellolio MF, Gilani W, Barrionuevo P, et al. Incidence of Adverse Events in Adults Undergoing Procedural Sedation in the Emergency Department: A Systematic Review and Meta $\square$ analysis. Academic Emergency Medicine. 2016; 23(2): 119-134.

29. Bellolio M F, Puls H, Anderson J, et al. Incidence of adverse events in paediatric procedural sedation in the emergency department: a systematic review and meta-analysis. BMJ Open. 2016; 6(6):e011384.

30. Becker D, Haas D. Management of Complications During Moderate and Deep Sedation: Respiratory and Cardiovascular Considerations. Anesthesia Progress. 2007; 54(2):59-69.

31. Nieuwenhuijs D, Sarton E, Teppema LJ, et al. Respiratory sites of action of propofol: absence of depression of peripheral chemoreflex loop by low-dose propofol. Anesthesiology. 2001; 95(4):889-95.

32. Odom-Forren J, Watson D. (2005) Practical Guide to Moderate Sedation/analgesia. Retrieved from http://books.google.com

33. Reber A. Airway Characteristics and Safe Management of Spontaneously Breathing Patients: Risks of Sedation and Analgesia and Changes in Wakefulness. IJCM. 2016; 7(11): 726-735.

34. Hernández-Cortez E. Update on the management of laryngospasm. Journal of Anesthesia and Critical Care Open Access. 2018; 8(2):1-6.

35. Nason K. Acute Intraoperative Pulmonary Aspiration. Thoracic Surgery Clinics. 2015; 25(3):301-7.

36. Reber LL, Hernandez JD, Galli SJ The pathophysiology of anaphylaxis. Journal of Allergy and Clinical Immunology. 2017; 140(2):335-348.

37. Goudra B, Nuzat A, Singh PM, et al. Cardiac arrests in patients undergoing gastrointestinal endoscopy: A retrospective analysis of 73,029 procedures. Saudi journal of gastroenterology: official journal of the Saudi Gastroenterology Association. 2015; 21(6):400-11.

38. Crosby G, Culley DJ, \& Marcantonio ER. Delirium: a cognitive cost of the comfort of procedural sedation in elderly patients? Mayo Clinic proceedings. 2010; 85(1), 12 4.

39. Munk L, Andersen G, Møller AM. Post-anaesthetic emergence delirium in adults: incidence, predictors and consequences. Acta Anaesthesiologica Scandinavica. 2016; 60(8):1059-66.

40. Gooden R, Tennant I, James B et al. The incidence of emergence delirium and risk factors following sevoflurane use in pediatric patients for day case surgery, Kingston, Jamaica. Brazilian Journal of Anesthesiology. 2014; 64(6):413-8.

41. Sinclair R, Faleiro R. Delayed recovery of consciousness after anaesthesia. Continuing Education in Anaesthesia Critical Care \& Pain. 2006; 6(3):114-118

42. Conway A, Kennedy W, Sutherland J. In- 
advertent Hypothermia After Procedural Sedation and Analgesia in a Cardiac Catheterization Laboratory: A Prospective Observational Study. Journal of Cardiothoracic and Vascular Anesthesia. 2015; 29(5):1285-90.

43. Díaz M, Becker DE. Thermoregulation: physiological and clinical considerations during sedation and general anesthesia. Anesthesia progress. 2010; 57(1):25-32; quiz 33-

44. Rosenberg $\mathrm{H}$, Pollock $\mathrm{N}$, Schiemann A, et al. Malignant hyperthermia: a review. Orphanet journal of rare diseases. 2015; 10:93.

45. Horn CC, Wallisch WJ, Homanics GE, Williams JP. Pathophysiological and neurochemical mechanisms of postoperative nausea and vomiting. European Journal of Pharmacology. 2013; 722:55-66.

46. Baldini $\mathrm{G}$, Bagry $\mathrm{H}$, Aprikian A et al. Postoperative urinary retention: anesthetic and perioperative considerations. Anesthesiology. $2009 ; 110(5): 1139-57$.

47. Beach ML, Cohen DM, Gallagher SM et al. Major Adverse Events and Relationship to Nil per Os Status in Pediatric Sedation/ Anesthesia Outside the Operating Room: A Report of the Pediatric Sedation Research Consortium. Anesthesiology. 2016; 124(1):80-8

48. Green SM, Mason KP, Krauss BS. Pulmonary aspiration during procedural sedation: a comprehensive systematic review. BJA. 2017; 118(3):344-354

49. Trevisani L, Cifala V, Gilli G, Matarese V, Zelante A, Sartori S. Post-Anaesthetic Discharge Scoring System to assess patient recovery and discharge after colonoscopy. World Journal of Gastrointestinal Endoscopy.2013; 5(10):502-507.

50. Hickey N, O'Leary M, Falk V, Borgaonkar $M$. When it it safe to discharge patients following colonoscopy? Validation of the Aldrete score. [online] Sages.org. Available at: https://www.sages.org/meetings/annual-meeting/abstracts-archive/when-is-itsafe-to-discharge-patients-following-colonoscopy-validation-of-the-aldrete-score/ [Accessed 24 Oct. 2018].

51. Newman DH, Azer MM, Pitetti RD, et al. When is a patient safe for discharge after procedural sedation? The timing of adverse effect events in 1367 pediatric procedural sedations. Annals of Emergency Medicine. 2003; 42(5):627.

52. Cohen, J. (2018). Overview of procedural sedation for gastrointestinal endosco- py. [online] Uptodate.com. Available at: https://www.uptodate.com/contents/overview-of-procedural-sedation-for-gastrointestinal-endoscopy [Accessed 24 Oct. 2018].

53. Lichtenstein DR, Jagannath $\mathrm{S}$, Baron $\mathrm{TH}$, Anderson MA, Banerjee S, Dominitz JA et al. Sedation and anesthesia in GI endoscopy. Gastrointestinal Endoscopy.2008; 68(5): $815-826$.

54. Ferreira AO, Cravo M. Sedation in gastrointestinal endoscopy: Where are we at in 2014?. World Journal of Gastrointestinal Endoscopy. 2015; 7(2):102-109.

55. Amornyotin, S. Sedation and monitoring for gastrointestinal endoscopy. World Journal of Gastrointestinal Endoscopy. 2013; 5(2):47-55.

56. Almashhrawi AA, Rahman R, Jersak ST, Asombang AW, Hinds AM, Hammad HT et al. Prophylactic tracheal intubation for upper GI bleeding: a meta-analysis. World Journal of Meta-analysis. 2015; 3(1):4-10.

57. Bradley, LD. (2018). Overview of hysteroscopy. [online] Uptodate.com. Available at: https://www.uptodate.com/contents/overview-of-hysteroscopy [Accessed 24 Oct. 2018].

58. Centini G, Calonaci A, Lazzeri L, Tosti C, Palomba C, Puzzutiello R et al. Parenterally administered moderate sedation and paracervical block versus general anesthesia for hysteroscopic polypectomy: a pilot study comparing postoperative outcomes. Journal of minimally invasive gynecology. 2015;22(2):193-198.

59. Asgari Z, Razavi M, Hosseini R, Nataj M, Rezaeinejad M, Sepidarkish M. Evaluation of Paracervical Block and IV Sedation for Pain Management during Hysteroscopic Polypectomy: A Randomized Clinical Trial. Pain Research and Management. 2017; 1-7

60. Kwan I, Wang R, Pearce E, Bhattacharya $\mathrm{S}$. Pain relief for women undergoing oocyte retrieval for assisted reproduction. Cochrane Database of Systematic Reviews. 2018.

61. Chestnut DH, Wong CA, Tsen LC, Ngan Kee WD, Beilin Y, Mhyre JM, et al. Chestnut's Obstetric anesthesia: Principles and Practice. 5th ed. Philadelphia: Elsevier Saunders; 2014

62. Hamid M. Anesthesia for cardiac catheterization procedures - a review article. Heart, Lung and Vessels. 2014; 6(4): 225-231.

63. Shook, DC. (2018). Anesthetic considerations for electrophysiology, interven- 
tional cardiology and transesophageal echocardiography procedures [online]. Uptodate.com. Available at: https://www. uptodate.com/contents/anesthetic-considerations-for-electrophysiology-interventional-cardiology-and-transesophageal-echocardiography-procedures [Accessed 24 Oct. 2018].
64. Youn A, Ko Y, Kim Y. Anesthesia and sedation outside of the operating room. Korean Journal of Anesthesiology. 2015; 68(4):323.

65. K, Jaggar S, Gilbe C. The anaesthetist and the cardiac catheterization laboratory - a review article. Anaesthesia. 2006; 61:11751186. 